University of Wollongong

Research Online

Faculty of Law, Humanities and the Arts Papers (Archive)

Faculty of Arts, Social Sciences \& Humanities

$1-1-2019$

The imitation game: Mock Foods in the Australian Women's Weekly, 1933-82

Lauren Samuelsson

University of Wollongong, ljs743@uowmail.edu.au

Follow this and additional works at: https://ro.uow.edu.au/lhapapers

Part of the Arts and Humanities Commons, and the Law Commons

Research Online is the open access institutional repository for the University of Wollongong. For further information contact the UOW Library: research-pubs@uow.edu.au 


\title{
The imitation game: Mock Foods in the Australian Women's Weekly, 1933-82
}

\author{
Abstract \\ This article explores the rise and demise of mock food in Australian food culture by analysing recipes \\ drawn from the pages of the Australian Women's Weekly. Mock foods were approximations and \\ substitutions for 'the real thing' and were especially popular during the years of austerity and scarcity \\ generated by the Great Depression and World War II. The fluctuating popularity of these foods, including \\ mock chicken and mock cream, reveals the shifting cultural importance of various foodstuffs to the \\ Australian diet. Their appearance also demonstrates the remarkable ability of Australian domestic cooks, \\ especially women, to adopt, adapt and innovate, an important attribute of Australian food culture. \\ Disciplines \\ Arts and Humanities | Law \\ Publication Details \\ Samuelsson, L. (2019). The imitation game: Mock Foods in the Australian Women's Weekly, 1933-82. \\ Australian Historical Studies, Online First 1-17.
}




\section{The Imitation Game:}

\section{Mock Foods in the Australian Women's Weekly, 1933-82}

\section{LAUREN SAMUELSSON}

This article explores the rise and demise of mock food in Australian food culture by analysing recipes drawn from the pages of the Australian Women's Weekly. Mockfoods were approximations and substitutions for 'the real thing' and were especially popular during the years of austerity and scarcity generated by the Great Depression and World War II. The fluctuating popularity of these foods, including mock chicken and mock cream, reveal the shifting cultural importance of various foodstuffs to the Australian diet. Their appearance also demonstrates the remarkable ability of Australian domestic cooks, especially women, to adopt, adapt and innovate, an important attribute of Australian food culture.

\footnotetext{
Marrow masquerades as pineapple,

custard squash as apple, mutton as ham,

and a vegetable mixture as a savory

"sausage" in prize recipes given below. ${ }^{1}$
}

On the first of January 1944, when the above article appeared in the Australian Women's Weekly (the Weekly), Australian housewives were preparing themselves for the introduction of meat rationing - the last in a line of restrictions that the Australian government had introduced during World War II. The article presented six recipes submitted by readers, four of which were 'mock foods' - approximations and substitutions for the 'real thing'. The recipe that won first prize, 'Mock Pineapple' by Mrs A. T. Robson, substituted fresh

\footnotetext{
1 'Make-do recipes win prizes', Australian Women's Weekly (The Weekly), 1 January 1944, 24.
} 
pineapple with vegetable marrow stewed with sugar and lemon, to be served with custard. This recipe was joined by others for 'Mock Apples', 'Christmas Mock Ham' and 'Meatless Sausage'. ${ }^{2}$ The prevalence of mock food recipes in this popular women's magazine suggest that they were an important part of Australian food culture. In 1969, the Weekly itself noted the past popularity of mock food recipes in a brief piece that reflected nostalgically on a time, twenty-five years past, when 'Out of six recipes on a page' of the Weekly, 'four were "mock"" ${ }^{3}$ By the 1970s, mock foods had all but disappeared from Australian tables. By examining recipes drawn from the pages of the Weekly, Australia's most popular women's magazine, this article explores the phenomenon of mock foods and what they reveal about Australian food culture in the twentieth century.

Australian culinary culture has been influenced by governmental nutrition guidelines, the availability of ingredients and various social factors such as migration, travel, popular recipe books, magazines, and advertisers. ${ }^{4}$ During the 1950s and 1960s, the Weekly had the highest circulation of any magazine per capita in the world and was read in approximately 25 per cent of Australian homes. ${ }^{5}$ While the Weekly's target audience was primarily white, middle-class women, evidence suggests that the magazine was read by all socio-economic groups, including men. ${ }^{6}$ This wide readership gave the Weekly an immense social and cultural influence, establishing it as a force in shaping, among other things, Australian domestic food culture. The Weekly featured cookery columns from its first edition in June 1933, and these became one of the iconic components of the magazine. A survey conducted as a part of my

\footnotetext{
This research has been conducted with the support of the Australian Government Research Training Program Scholarship. No potential conflict of interest was reported by the author.

2 'Make-do recipes win prizes', Australian Women's Weekly (The Weekly), 1 January 1944, 24.

3 'In the Australian Women's Weekly...25 Years Ago', The Weekly, 1 January 1969, 27.

${ }^{4}$ Beverley Kingston, 'Are We What We Eat?', in The Abundant Culture: Meaning and Significance in Everyday Australia, eds David Headon, Joy Hooten, and Donald Horne (Sydney: Allen \& Unwin, 1994), 125.

${ }^{5}$ Susan Sheridan, Barbara Baird, Kate Borrett, and Lyndall Ryan, Who Was That Woman? The Australian Women's Weekly in the Postwar Years (Sydney: University of New South Wales Press, 2002), 1.

${ }^{6}$ Bridget Griffen-Foley, The House of Packer: The Making of a Media Empire (Sydney: Allen \& Unwin, 1999), 67.
} 
wider research project has verified the impact of the Weekly on the Australian kitchen. Of the 161 responses to the survey, 103 participants born between 1930 and 1979 indicated that the cookery section was one of the reasons (often the only reason) they purchased the magazine. Respondents believed the recipes from the Weekly were 'reliable', 'triple tested', and 'guaranteed to be successful'. ${ }^{7}$

While the influence of the Weekly on Australian domestic food culture has been recognised by historians, there has not been an in-depth study of how food culture was communicated and constructed within its pages. ${ }^{8}$ Domestic food culture in Australia cannot be studied without consideration of women's texts, such as the Weekly, as domestic food preparation was (and often still is) a responsibility associated with women. ${ }^{9}$ Food has meaning beyond its nutritional qualities, and a study of food and drink can reveal how 'what we eat ... signals ... who we are'. ${ }^{10}$ Thus, by undertaking an analysis of mock foods in the Weekly, this article contributes to Australian cultural, gender and culinary history.

Despite acknowledgement of their importance, there is very sparse scholarship on mock foods in Australian food history. ${ }^{11}$ This article argues that the appearance of mock foods in the Weekly speaks to an important underlying attribute of Australian food culture: the willingness to adapt, improvise, innovate and break the 'rules'. ${ }^{12}$ Mock foods are not

\footnotetext{
${ }^{7}$ Lauren Samuelsson, “A Matter of Taste": the Australian Women's Weekly and the birth of a modern Australian food culture, 1933-1982' (Survey, University of Wollongong, 2018).

${ }^{8}$ Colin Bannerman, Seed Cake and Honey Prawns: Fashion and Fad in Australian Food (Canberra: National Library of Australia, 2008), 26-27; Susan Sheridan, 'Eating the Other: Food and Cultural Difference in the Australian Women's Weekly in the 1960s', Journal of Intercultural Studies 21, no. 3 (2000); Sheridan et al., Who Was That Woman; Gwendolyn Stansbury, 'The Making of a Multicultural Palate: The Diffusion of Italian Food in Australia, 1945-1975' (PhD Thesis, University of New England, 2005), 173-204.

${ }^{9}$ David Bell and Gill Valentine, Consuming Geographies: We Are Where We Eat (London: Routledge, 1997), 69-72.

${ }^{10}$ Ibid., 3 .

${ }^{11}$ Sarah Black, "“Tried and Tested": Community Cookbooks in Australia, 1890-1980' (PhD Thesis, University of Adelaide, 2010), 35; Colin Bannerman, A Friend in the Kitchen: Old Australian Cookery Books (Sydney: Kangaroo Press Pty Ltd, 1996), 155-56.

${ }^{12}$ Cherry Ripe, Goodbye Culinary Cringe (Sydney: Allen \& Unwin, 1993), 233-34; Barbara Santich, Bold

Palates: Australia's Gastronomic Heritage (Adelaide: Wakefield Press, 2012), 303.
} 
particular to Australia. Britain and the United States of America also have a long history of mock food recipes such as 'Mock Turtle Soup' and 'Mock Apple Pie'. ${ }^{13}$ However, in the Australian cultural context, conditions and resources were notably different, leading to the popularity of different mock foods or recipes calling for different ingredients. Mock foods appeared in many guises. They were either designed to look like, or to taste like, the food they were imitating. Mock foods were inspired by scarcity, the availability of seasonal produce, climate, health concerns or the cost of the 'real thing' and they can inform us about the cultural importance of particular foods. ${ }^{14}$

Mock foods' disappearance post World War II reflects rapid changes in Australian food culture in the twentieth century, a result of increasing affluence and industrial food production. Between 1933 and 1982, Australian food culture underwent profound changes, from the traditional British 'meat-and-three-veg' style of cookery, to one of the most 'multiculinary' food cultures in the world. The traditional narrative of Australian food history proposes that, until postwar migrants arrived 'preaching the gospel of wine, olive oil and garlic', Australian domestic cuisine was emblematic of 'stultifying British precedents ... lacking in innovation or flair'. ${ }^{15}$ Australia was the land of overcooked mutton, vegetables boiled to within an inch of their life and plenty of cake. Often, the blame for this apparently 'horrendous' food has been laid at the feet of the Australian housewife, supposedly a result of their rabid consumerism and conservatism. ${ }^{16}$ However, as Beverley Kingston argues, this

\footnotetext{
${ }^{13}$ Bannerman, Seed Cake and Honey Prawns, 14-16; Patricia Roberts, 'In Praise of Mock Food', Gastronomica 3, no. 2 (2003): 17.

${ }^{14}$ Lynne M Olver, 'Mock Foods', in Eating Your Words, ed. William Grimes (Oxford: Oxford University Press, 2004), 101-04; Roberts, 'In Praise of Mock Food', 17.

${ }^{15}$ John Newton, Wogfood: An Oral History with Recipes (Sydney: Random House, 1996), 5; Felicity Newman and Mark Gibson, 'Monoculture Versus Multiculturalism: Trouble in the Aussie Kitchen', in Ordinary Lifestyles: Popular Media, Consumption and Taste, eds David Bell and Joanne Hollows (Maidenhead: McGraw-Hill Education, 2005), 84.

${ }^{16}$ Michael Symons, One Continuous Picnic: A Gastronomic History of Australia, 2nd ed. (Melbourne: Melbourne University Press, 2007), 155-68; John Newton, The Getting of Garlic: Australian Food from Bland to Brilliant (Sydney: NewSouth Publishing, 2018).
} 
interpretation disregards the effort that Australian women put into feeding their families given the limited choices and opportunities available to them at the time. It also unfairly judges the food practices of the past based on our contemporary habits, which are held to be more sophisticated and discerning. ${ }^{17}$ Evidence from the Weekly suggests that Australian women were far more experimental in the kitchen than they have been given credit for. Mock foods illustrate that rather than being 'plain cooks' held ransom to the whims of industrialisation, Australian women were inventive, responding to restrictions in the availability of culturally significant foods with ingenuity and good humour. If modern Australian food culture can be defined by our 'enthusiasm for new foods, our readiness to bend rules, our willingness to adopt, improvise and reinvent', then mock foods are integral to Australia's culinary history. ${ }^{18}$

This examination of mock foods is based on data harvested from Trove's digitised repository of the Weekly and is part of a larger project that seeks to trace and understand trends in Australian food culture, including mock foods. Data was collected on recipes from every edition of the magazine in March, June, September and December in five-year increments from 1933 to 1982 - a total of 177 editions. The occurrence of multiple recipes for mock food in this sample prompted deeper investigation. At times, the lines between mock foods and simple ingredient substitution are blurred. This article focuses only on those recipes that were acknowledged as imitations by the food editor or the contributor. This was assessed based on the name of the recipe and the accompanying commentary, with words such as 'mock', 'sham', 'imitation' and 'meatless' indicating the presence of a mock food. Keyword searches and harvesting on Trove led to the identification of 331 recipes for mock foods in the Weekly between 1933 and 1982. While this is not a large percentage of the total

\footnotetext{
${ }^{17}$ Beverley Kingston, 'When Did We Teach Our Girls to Cook?', Australian Cultural History 15 (1996): 90.

${ }^{18}$ Santich, 303.
} 
number of recipes that were published during these years, mock foods were conspicuous in their ingenuity and creativity. Although mock foods were present throughout this period, often in response to religious observances like Lent, this article focuses largely on the 1930s and 1940s, when these recipes proliferated and flourished.

Unsurprisingly, the majority of mock food recipes were published during the years of austerity generated by the Great Depression and World War II. A total of 211 recipes for mock food were published in the Weekly during the 1930s and 1940s, with 114 of those (54 per cent) published during the war years. ${ }^{19}$ The majority of these were submitted by readers to the weekly recipe competition. ${ }^{20}$ Recipes contributed by readers are more indicative of actual consumption than editorial recipes, so this suggests that the recipes were being cooked on a regular basis. ${ }^{21}$ Apart from a small spike in the 1960 s, which can be attributed to multiple recipes for mock cream, the publication of mock food recipes declined significantly after the 1940s. By the 1970s, the number of these recipes had dwindled with only ten recipes published during that decade.

\section{Mock foods: a response to scarcity}

An Australian tradition of mock food was well established by the time the Weekly was first published in June 1933. At that time, in the context of the Great Depression when families were grappling with unemployment and poverty, mock foods flourished. ${ }^{22}$ However, at a cost of $2 \mathrm{~d}$ (the same price as a pound of cheap sausage meat), the first editions of the Weekly were

\footnotetext{
19 This includes recipes submitted by readers, published in editorial features and in advertisements.

${ }^{20}$ A total of 130 reader-submitted recipes were submitted from 1933-49, compared to 75 published in editorial features.

${ }^{21}$ Colin Bannerman, 'Print Media and the Development of an Australian Culture of Food and Eating c.1850 to c.1920: The Evidence from Newspapers, Periodical Journals and Cookery Literature' (PhD Thesis, University of Canberra, 2001), 194.

${ }^{22}$ Popular mock foods in colonial times included mock duck, colonial goose and Australian venison.

Bannerman, A Friend in the Kitchen, 156.
} 
probably not purchased by those women hardest hit by the Depression. ${ }^{23}$ Nonetheless, very few families escaped the Depression without some change to their dietary habits. ${ }^{24}$ These changes mostly involved buying cheaper ingredients, substituting beef for mutton for example. Families also grew produce at home and collected food items by foraging, fishing and hunting. The reliance on cheap and available ingredients led to monotony; a diet of stew, bread and dripping. ${ }^{25}$ Understandably, housewives tried to make food, as the Weekly editors put it, more 'novel'. ${ }^{26}$

Australian households had barely recovered from the Depression when World War II enforced more austerity. Australia was spared the intense rationing experienced in Britain, where access to dietary staples such as meat, dairy, tea and sugar was restricted for over a decade. ${ }^{27}$ Nonetheless, Australia's role as the 'food arsenal for the allied world' did result in local food shortages. ${ }^{28}$ Rationing commenced with the regulation of tea in July 1942, sugar in August 1942, butter in June 1943 and meat in January 1944. Potatoes, eggs, bacon, tinned goods and fresh milk were also intermittently in short supply. ${ }^{29}$ Food shortages had a discernible effect on consumption practices. By 1944, poultry and game consumption had decreased by 31.5 per cent compared to 1939 , and the consumption of other meats had decreased by 16.1 per cent. Milk and milk products, as well as sugar, oils and fats and

\footnotetext{
23 'Housewives - Watch These Prices', The Weekly, 10 June 1933, 2.

${ }^{24}$ Humphrey McQueen, Social Sketches of Australia 1888-2001, 3rd. ed. (Brisbane: University of Queensland Press, 2004), 124-34; David Potts, The Myth of the Great Depression, 2nd. ed. (Melbourne: Scribe, 2009), 2349.

${ }^{25}$ Potts, 37-42.

${ }^{26}$ The concept of 'novelty' threads through the cookery features of the 1930s and 1940s. For example: 'Prize Offered for Novel Salad', The Weekly, 28 October 1933, 35; 'Novel Idea Wins First Prize', The Weekly, 5 November 1938, 62; 'Novel Recipes Win Prizes', The Weekly, 7 December 1940, 56.

${ }^{27}$ Somewhat surprisingly, given this context, mock foods have garnered little academic attention in British food history, although they have been addressed in popular histories. See, for example: Ina Zweiniger-Bargielowska, Austerity in Britain: Rationing, Controls and Consumption, 1939-1955 (Oxford: Oxford University Press, 2000), 112.

${ }^{28}$ Diana Christine Noyce, 'The Squander Bug: Propaganda and Its Influence on Food Consumption in Wartime Australia' (paper presented at the Oxford Symposium on Food and Cookery, Oxford, 2015), 306.

${ }^{29}$ Robin Walker and Dave Roberts, From Scarcity to Surfeit: A History of Food and Nutrition in New South Wales (Sydney: University of New South Wales Press, 1988), 112-13.
} 
tomatoes and citrus fruits, also saw declining consumption. ${ }^{30}$ In response to these shortages, Australian women shared and requested recipes in the Weekly to imitate the foods that they could not, or would not, do without.

Analysis of recipes in the Weekly demonstrates evidence of a wide variety of mock foods, from basic forms like mock fish and mock raspberry jam to more extravagant examples like mock pate de fois gras and mock champagne. In the 1930s and 1940s, economic austerity was woven into these recipes: cheaper cuts of meat were used; egg white stood in for cream; breadcrumbs for almond meal. Contributors to the magazine did not hide the fact that these recipes were an antidote for scarcity. The recipe for 'Whipped Austerity Cream' or 'Poor Man's Pate de Fois Gras' left little doubt that these were cheaper alternatives to the 'real thing'. ${ }^{31}$ Recipes for mock food were shared when particular foodstuffs were unavailable, reflecting the immediate impact of shortages on the Australian diet. For example, in September 1942, when potatoes, even seed potatoes, were scarce and exorbitantly priced, one reader contributed a recipe for 'Sham Potatoes' (flour and 'fat' dumplings). A further recipe for 'Mock Potatoes' appeared in late October that same year. ${ }^{32}$ As multicultural recipes became popular after World War II, other recipes in the Weekly reflected the inability of the average domestic cook to obtain 'adventurous' foods. A 1954 recipe for 'Mock Soya Sauce', for example, saw the Asian staple replicated with watered down Worcestershire sauce. ${ }^{33}$

\footnotetext{
${ }^{30}$ F.W. Clements, cited in Walker and Roberts, 113.

31 'Simple recipes with a difference', The Weekly, 11 March 1944, 28; 'Drinks and Savories', The Weekly, 2 December 1964, in lift out: 'A Cookery Book for Christmas Parties', 2.

32 'From our readers...Eight Meal Time Gems, The Weekly, 26 September 1942, 40; Olwen Francis, 'Countingthe-cost menus', The Weekly, 24 October 1942, 27; Walker and Roberts, 113.

33 'A Touch of Garlic', The Weekly, 3 February 1954, 51.
} 


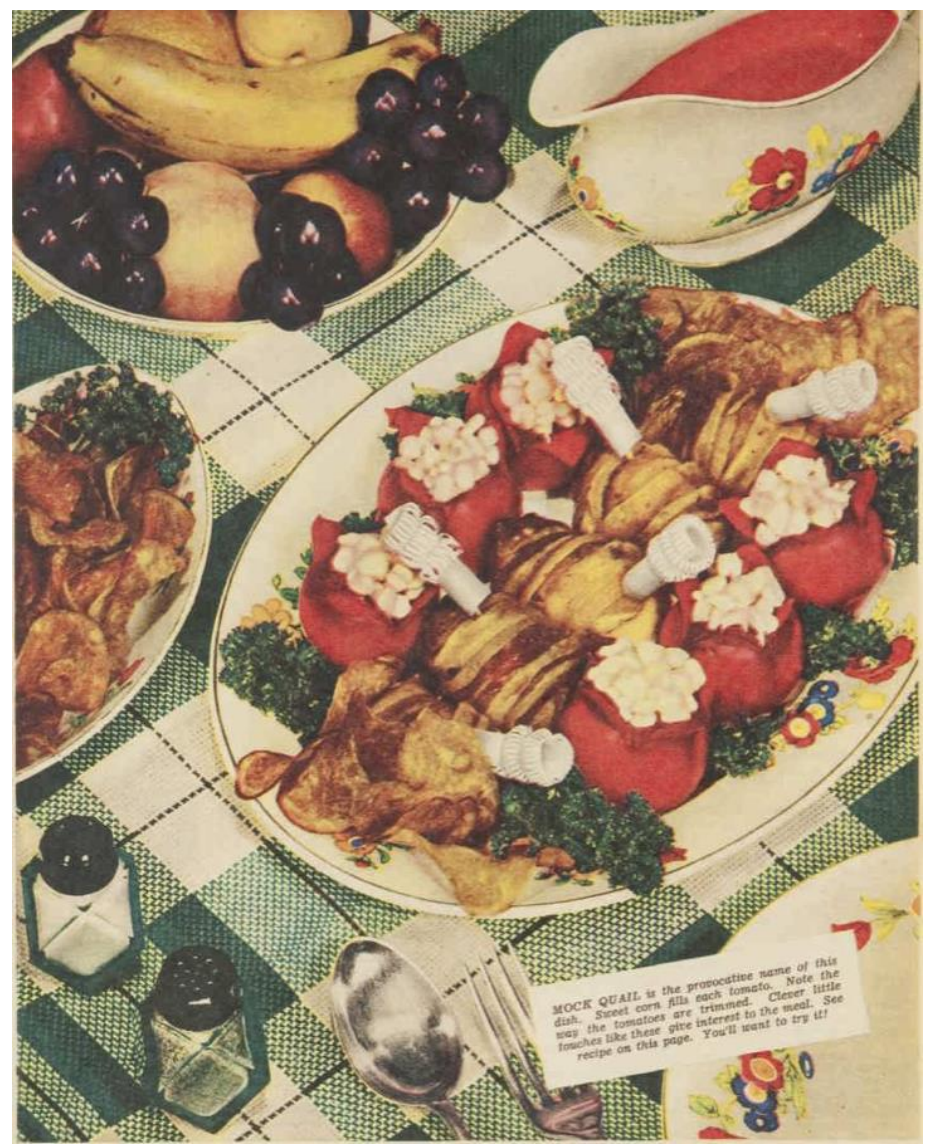

Figure 1: This image accompanied a recipe for 'Mock Quail'. The 'quail' was thinly sliced veal wrapped around a breadcrumb dumpling. Note the fringed 'bones'. Mary Forbes, 'Warm Weather Dishes', The Weekly, 21 February 1942, 34.

Some mock food recipes were published multiple times in the magazine, including instructions for the preparation of mock oysters, mock marzipan, mock ham and mock eggs. Below, I explore two mock foods that were particularly popular, in order to demonstrate the importance of mock foods to Australian food culture. Mock chicken recipes display the general trajectory of all mock foods: a high level of popularity when the ingredient was scarce or expensive, followed by a subsequent disappearance once the ingredient became readily accessible. Mock cream, on the other hand, is an exception to this rule. It is the one mock food that remains widely popular in Australian diets to this day. While other mock 
foods were usually a response to scarcity, mock cream was adopted for different purposes, not least as a response to Australia's hot climate. This has contributed to its enduring place in Australian food culture.

\section{The rise and demise of mock chicken}

Today, Australians are among the world's highest consumers of chicken meat. ${ }^{34}$ However, before the implementation of modern chicken farming practices in the mid-twentieth century, chicken was a novelty - a dish served on celebratory occasions. Prior to the pre-packaged, frozen supermarket product of the 1970s, roasting a chicken was, as Jane Dixon puts it, 'an act of love, a symbol of a special occasion, a rare treat signalling a religious holiday, ${ }^{35}$ Annual consumption of chicken meat skyrocketed over the years considered by this article, from a yearly average of $4.4 \mathrm{~kg}$ per capita during the $1930 \mathrm{~s}$ and $1940 \mathrm{~s}$, to $21 \mathrm{~kg}$ per capita, per annum, by 1984. This increasing consumption is linked to the introduction of agribusiness processes which grew chickens faster and with less feed, and subsequently made chicken meat more affordable. ${ }^{36}$ Certainly, in the 1930s and 1940s chicken was costly. In 1943, the Commonwealth Prices Commissioner, who protected Australians from wartime inflation and profiteering, set the maximum price of an uncooked, dressed chicken at $3 / 6 \mathrm{~d}$ per pound. ${ }^{37}$ That made it prohibitively expensive against the maximum $1 \mathrm{~d}$ charged for a pound of topside beef. ${ }^{38}$ Unsurprisingly, recipes for mock chicken proliferated during the 1930s and 1940s. Mock poultry (including chicken, quail, goose and duck) made up around 20 per cent of all

\footnotetext{
${ }^{34}$ OECD data shows Australians consume $44.5 \mathrm{~kg}$ of poultry meat per capita per annum, compared to $37.9 \mathrm{~kg}$ in New Zealand and 24.2kg in the European Union. See OECD, Meat Consumption Indicator. 2018. https://data.oecd.org/agroutput/meat-consumption.htm (accessed 15 July 2018).

35 Jane Dixon, The Changing Chicken: Chooks, Cooks and Culinary Culture (Sydney: University of New South Wales Press, 2002), 3.

${ }^{36}$ Walker and Roberts, 121-22.

37 'National Security (Prices) Regulations', Commonwealth of Australia Gazette, 29 November 1943, 2606.

38 'National Security (Prices) Regulations', Commonwealth of Australia Gazette, 13 April 1943, 836.
} 
mock food recipes published in the Weekly: a total of 67 recipes over the 49 years from

1933-82. Of these, just over half were recipes for mock chicken, most published during the 1930s and 1940s. ${ }^{39}$ During the 1970s the Weekly published no recipes for mock chicken at all. ${ }^{40}$ Thus the Weekly clearly illustrates the changing place of chicken in Australian food culture, from a time when home cooks needed to create alternatives to a more modern style of chicken consumption, where chicken is an affordable everyday protein.

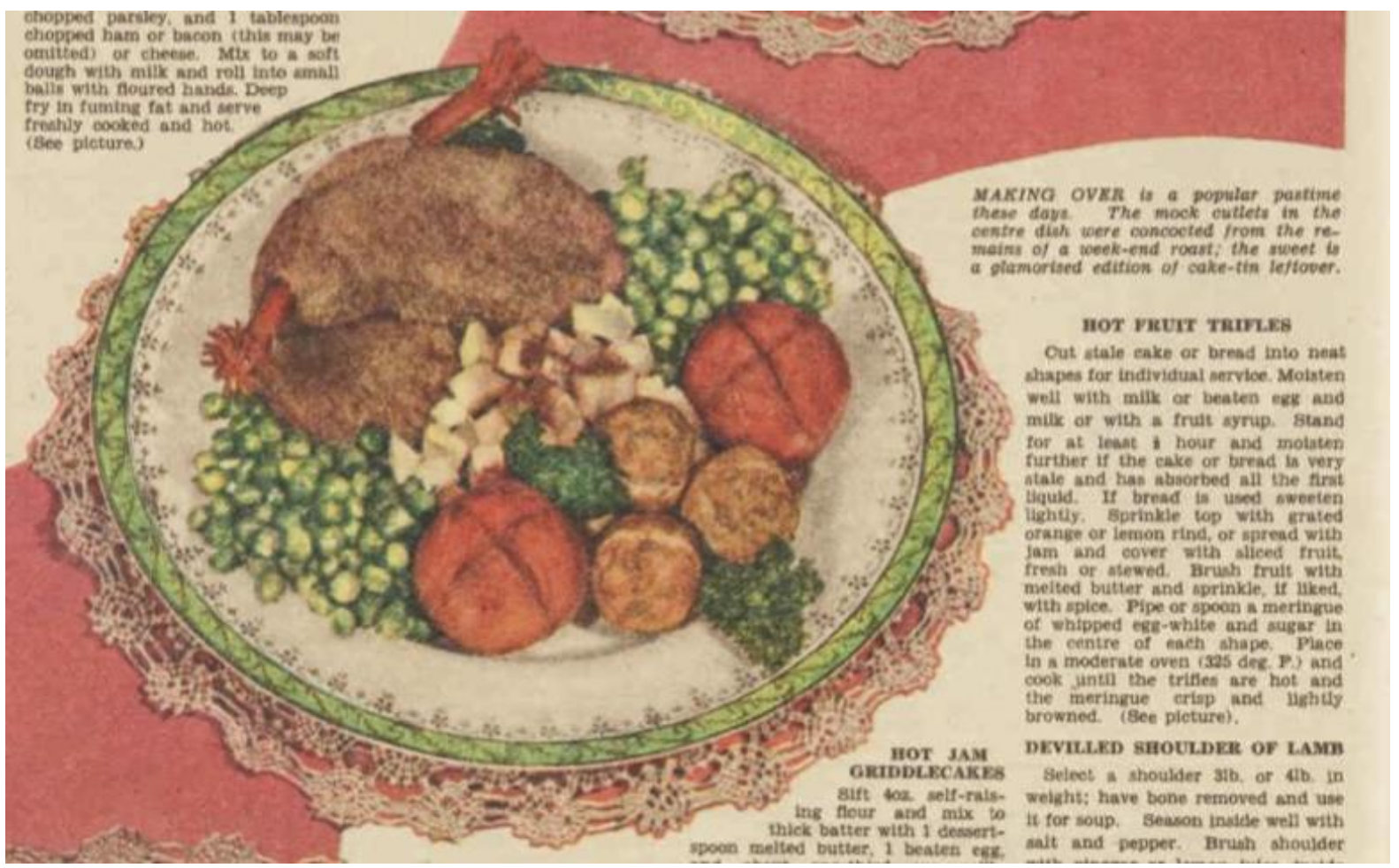

Figure 2 These 'Mock Chicken Cutlets' were made with leftover meat, either mutton, veal or rabbit, shaped to look like a chicken maryland and fried. Olwen Francis, 'Olwen Francis gives you.... Personality Menus', The Weekly, 10 October 1942, 26.

\footnotetext{
${ }^{39}$ The remainder were recipes for other mock poultry such as mock duck, mock goose and mock squab.

${ }^{40}$ Of the 35 recipes for mock chicken, five were published in the 1930s and 16 in the 1940s. From there, there was a decline, with 10 recipes published during the 1950 s and only four during the 1960 s.
} 
During the 1930s and 1940s, enterprising cooks created numerous dishes that fell into the category of mock chicken: mock chicken croquettes, for example, as well as mock chicken mould, mock chicken cutlets, mock chicken loaf and the popular mock chicken pie. Rabbit was by far the most common protein substituted for chicken in these recipes; two thirds of mock chicken recipes used rabbit as an alternative. The use of rabbit as a substitute for chicken reveals the influence of austerity on the Australian diet. Rabbit meat is highly regarded in other food cultures, including in British cuisine where 'mock chicken' existed but was primarily a nut-based vegetarian substitute. ${ }^{41}$ In twentieth century Australia, however, rabbit was largely seen as a meat of necessity, if not poverty, as reflected in euphemistic names like 'underground mutton' and 'poor man's chicken'. ${ }^{42}$ As historian David Potts discovered when researching his oral history of the Great Depression, memories of food during the 1930s are infused with rabbits. ${ }^{43}$ A cheap (sometimes free) but monotonous diet consisting of 'stewed rabbit, baked rabbit, roast rabbit, fried rabbit, and fricasseed rabbit' led to many children of the Depression vowing to 'never eat another rabbit as long as they lived'. ${ }^{44}$

Statistics also show a spike in rabbit consumption during World War II. Australians ate up to 27 million rabbits a year during the 1940s. ${ }^{45}$ An unrationed protein, rabbits, like offal and sausages, became a food of necessity once meat rationing was introduced in 1944. Olwen Francis, the Weekly's food editor at the time, addressed the tedium of consuming rabbit in a feature titled 'Any way you like 'em ... Rabbit Dishes'. Francis claimed that,

\footnotetext{
${ }^{41}$ A search on the British Newspaper Archive indicates that while recipes for mock chicken appear in British newspapers, the substituted ingredients differ from those in Australia. Primarily, mock chicken recipes in Britain were vegetarian, using ground nuts for the substitution. Those recipes that did substitute meat for chicken used veal, pork or mutton.

${ }^{42}$ Brian Coman, Tooth and Nail: The Story of the Rabbit in Australia (Melbourne: Text Publishing, 1999), 9697.

${ }^{43}$ Potts, 41.

${ }^{44}$ Len Fox, Depression Down Under (Sydney: Southwood Press, 1977), 113.

${ }^{45}$ Warwick Eather and Drew Cottle, 'The Rabbit Industry in South-East Australia, 1870-1970' (paper presented at the 14th Biennial Labour History Conference, Melbourne, 2015).
} 
'With some of us our very familiarity with the rabbit leads to culinary contempt. But ... epicures find it as delicate to the palate as a tender bird. It is worthy of a place on the weekly menu'. After prompting housewives to remember the gustatory virtues of rabbit - tellingly describing it as bird-like - Francis offered recipes for rabbit prepared in a multitude of ways, although the recipes for baked rabbit, rabbit casserole, and rabbit pie hardly pushed the boundaries of inventive rabbit preparation. ${ }^{46}$

One way of addressing boredom with a rabbit-centric diet was to prepare it in the form of mock food, transforming the unexciting, mundane protein into something special. Olwen Francis' July 1944 recipe for 'Mock Chicken Chow Mein' would have been an intriguing recipe for the war-time housewife to emulate. This, the first mention of 'chow mein' in the Weekly, and one of the earliest 'Chinese-style' recipes shared in the magazine, used rabbit as a substitute for chicken.

\section{MOCK CHICKEN CHOW MEIN}

One cup diced celery, 1 small sliced onion, 11/2 cups rabbit stock, 1 teaspoon flour, 1 tablespoon water, 1 cup sliced mushrooms, 1 teaspoon soy or Tabasco or Worcestershire sauce, 2 cups shredded cooked rabbit meat, pepper and salt, $21 \frac{1}{2}$ cups cooked noodles or macaroni or 4 slices hot buttered toast.

Cook the celery and onion in the stock until tender. Add the flour blended with the water, bring to the boil, and then add the mushrooms, sauce, rabbit meat. Simmer 10 minutes, add correct seasoning to taste. Serve piping hot with noodles, macaroni, toast, or vegetables. May be garnished with chopped celery leaves and sliced hard-boiled egg. For four. ${ }^{47}$

This recipe shows a great deal of innovation and creativity, though its authenticity is dubious at best. Whether or not the Weekly's readers cooked the adventurous 'Mock Chicken Chow

\footnotetext{
${ }^{46}$ Olwen Francis, 'Any way you like 'em... Rabbit Dishes', The Weekly, 22 April 1944, 27.

${ }^{47}$ Olwen Francis, 'Family Dinners', The Weekly, 29 July 1944, 22.
} 
Mein', Olwen Francis raised the possibility that rabbit could be less monotonous and pleasing for the family. As she put it, 'Mock Chicken Chow Mein' was 'penny-conscious, interesting to prepare and to eat! ${ }^{48}$

Rabbit was not the only alternative for chicken meat, however. A recipe for 'Savory Mock Chicken Pie', submitted to the weekly recipe competition by Miss M. Bell in February 1946, demonstrates the culturally transformative powers of mock foods.

\section{SAVORY MOCK CHICKEN PIE}

One pound tripe, 1 onion, 3 or 4 thick slices of stale bread, 1 egg, 1 tablespoon chopped parsley, $1 / 4$ teaspoon thyme, salt and pepper, squeeze of lemon, $11 \mathrm{~b}$ green peas, 1 dessertspoon butter.

Blanch the tripe and cut into small pieces. Cover with water, add onion and 1 teaspoon salt and simmer until tender, about 1 hour. Make a seasoning by moistening the bread with the tripe stock, add chopped onion from the stock, beaten egg, chopped parsley, thyme and lemon, pepper and salt to taste. Place a layer of bread seasoning in a greased ovenproof dish, cover with tripe, then cooked green peas. Lastly cover with a layer of seasoning and dot with butter. Bake in a moderate over (375deg. F.) for 45 minutes.

First Prize of $£ 1$ to Miss M. Bell, 32 Esplanade, Semaphore, S.A. ${ }^{49}$

This recipe replaces chicken with tripe, another unrationed protein. Australians have historically had a complicated relationship with offal consumption as, like rabbit, it was generally associated with poverty. In a revealing statement regarding attitudes towards offal in the interwar period, the 1936 report of the Advisory Council on Nutrition claimed that Australians, particularly those on lower incomes, harboured 'a deeply-rooted prejudice... against the eating of internal organs'. The Council claimed that it was 'class consciousness', rather than any superior nutritional value, that led the 'Australian on low income' to 'demand only those cuts of meat which are popularly regarded as superior - steak, choice chops, and

\footnotetext{
48 Ibid.

49 'Family Specials', The Weekly, 9 February 1946, 38.
} 
sirloins ${ }^{50}$ Indeed, Australians have historically celebrated the ability of all classes to eat meat. Writing in the late-nineteenth century, Englishman Richard Twopeny claimed that 'meat is the staple of Australian life. A working-man whose family did not eat meat three times a day would indeed be a phenomenon'. ${ }^{51}$

Culturally, 'superior meat' consumption reflected status, and so the primarily middleclass readers of the Weekly clung to 'superior' meat-eating as best they could. Even within the category of offal or 'variety meats' - as they were euphemistically called in the Weekly there was a 'hierarchy'. According to Stephen Mennell, the hierarchy of taste within the offal category in the Anglo-centric world ranges, in order of increasing repulsiveness, as follows: liver, kidneys, tongue, sweetbreads, brains, tripe, testicles and eyes. ${ }^{52}$ The 'mock chicken pie' recipe submitted by Miss Bell was made with tripe - the offal at the less palatable end of Mennell's spectrum. Of course, 'Savory Mock Chicken Pie' had a more sophisticated and enticing ring to it than 'Tripe Pie'. For her efforts in rendering tripe palatable, Miss Bell won a prize of one pound. ${ }^{53}$

An editorial feature in April 1962 indicated that by the early 1960s chicken was becoming affordable enough to be consumed by families on a regular basis. Leila C. Howard, the nom de plume of a series of food editors of the Weekly from the 1950s onwards, claimed:

Scientific farming is helping to reduce the price of chicken and these recipes using additional moderately priced ingredients make it a reasonable family meal instead of a luxury dish...

AUSTRALIAN poultry breeders are doing a great amount of research into chicken farming in order to produce better table birds. This research is mainly concentrated on diet and

\footnotetext{
${ }^{50}$ Advisory Council on Nutrition, 'First Report of the Advisory Council on Nutrition', ed. Department of Health (Canberra: Commonwealth Government Printer, 1936), 6.

${ }^{51}$ Richard Twopeny quoted in Bannerman, A Friend in the Kitchen, 16.

${ }^{52}$ Stephen Mennell, All Manners of Food: Eating and Taste in England and France from the Middle Ages to the Present (Oxford: Basil Blackwell Ltd, 1986), 311.

53 'Family Specials', The Weekly, 9 February 1946, 38.
} 
scientific selection of birds for breeding, the aim being to produce birds which have more meat per pound at less cost per pound than the previous layer-cum-table-bird varieties.

So successful are their efforts proving that in the near future bigger, tastier chickens will be on sale to the housewife at a cost comparable with the average meat price. ${ }^{54}$

There was, of course, the caveat that the other ingredients that went into a meal should be economical, but clearly chicken was on its way to becoming affordable and therefore popular. This growing affordability brought an end to the interest in various chicken substitutes. By the 1970s, there was no reason to fake it any longer: chicken was culturally transformed. A protein that was once the preserve of the wealthy became a lower-status takeaway food, assisted by the opening of the first Kentucky Fried Chicken restaurant in $1968 .{ }^{55}$ Many other mock foods followed the same path, and over time the variety of mock foods dwindled considerably. By the 1970s, only three different types of mock foods appeared in the magazine. These included mock roast meats made from nuts and lentils, and mock ham made from lamb. The other imitation recipe, which alone stood the test of time and avoided the vagaries of economic trends, was for mock cream.

\section{Mock Cream's journey from scarcity to necessity}

Recipes for mock cream were ubiquitous on the pages of the Weekly, and it can still be found filling cream buns, butterfly cakes, neenish tarts and lamingtons. Mock cream has transformed from an imitation of real cream in times of scarcity to become an enduring and essential component in some of Australia's best-loved baked goods. Recipes for mock cream appeared during all five decades of the study period and had the largest occurrence of any single recipe, with a total of 70 recipes published over 49 years. When taking into account

\footnotetext{
${ }^{54}$ Leila C Howard, 'Chicken - family style', The Weekly, 12 April 1961, 43-44.

${ }^{55}$ Walker and Roberts, 122.
} 
references to mock cream as an ingredient (rather than a substitute) in various recipes, that number increases to almost 300 . Primarily made from a combination of butter or margarine and sugar, mock cream was, in most cases, used as a substitute for whipped cream. While mock cream is used to fill and sometimes top cakes, it is distinctly different from modern 'buttercream' by virtue of its ingredients, the method of making it and the resulting product. It is generally softer and fluffier than buttercream. ${ }^{56}$ The longevity of mock cream in comparison to other imitation foods indicates that its popularity was for reasons other than austerity or scarcity. In turn, its popularity indicates the importance of Australia's baking tradition, where mock cream was often used for its shelf-stable properties. In an era before home refrigeration, fresh cream was not suitable for the hot Australian climate, given that dairy products had to travel long distances. ${ }^{57}$

Historian Beverley Kingston remembers mock cream as a staple of her childhood in tropical Queensland:

Fresh cream was a rarity. It didn't keep in the tropics and once you put it on the cake, it had to be eaten fairly quickly. Putting the cake in the fridge to keep the cream from going off made the cake go soft so the real pleasure of the sponge -its crisp outside and light as a feather inside - was lost. So we used mock cream..$^{58}$

Procuring fresh cream was often difficult for those in the city, whether tropical or not, before refrigerated transportation was introduced. A recipe for mock cream, published in Lismore's Northern Star in 1877 claimed that city-dwellers could only get 'real cream' at 'exorbitant

\footnotetext{
${ }^{56}$ See, for example: 'Finer Points of Cake Making', The Weekly, 16 Pages of Cookery Supplement, 10 July 1937, 1; 'Butter Substitute', The Weekly, 10 November 1945, 31; 'Popular Patty Cakes', The Weekly, 14 February 1973, 69.

${ }^{57}$ In 1944 it was estimated that only 6 per cent of Sydney homes had a refrigerator and 33 per cent were using ice chests. The remaining 61 per cent of homes had no refrigeration. Walker and Roberts, 142.

${ }^{58}$ Beverley Kingston, 'From Patty Cake to Cup Cake: The Treatment of Little Cakes in Australian Cookbooks since the Late Nineteenth Century', in Eat History: Food and Drink in Australia and Beyond, eds Sofia Eriksson, Madeleine Hastie, and Tom Roberts (Newcastle Upon Tyne: Cambridge Scholars Publishing, 2013), 77.
} 
prices' and so 'we try to use [milk] by transforming it into mock cream, with pretty good success too, we think'. The recipe called for milk with cornflour or arrowroot to thicken. With the addition of sugar and eggs, it bore more resemblance to a custard than to cream, although as the article pointed out 'city people really [knew] very little about...genuine cow's cream' ${ }^{59}$ The supply of uncontaminated milk, butter and cream continued to be a problem even after the advent of refrigeration, entrenching mock cream as a necessary element of Australian food culture. For example, during the early 1930s, housewives were irritated by the preservatives which were added to cream to avoid spoilage. They claimed that cream with the additives refused to 'whip' and could not, therefore, make successful cakes and sweets. ${ }^{60}$ It was easier for the discerning housewife to make her own dependable imitation of the real thing.

Recipes for mock cream varied considerably, and they were highly sought after. In one 1935 editorial feature, food editor Ruth Furst noted that 'From time to time I have received letters from readers asking for the correct way to make mock cream'. She knew of 'no fewer than four different ways of making mock cream'. ${ }^{61}$ Mock cream was considered integral to good food, according to Furst: 'Many a good hostess knows just how much a tasty filling has been responsible for turning an otherwise disappointing culinary effort into a delectable success.' All four mock cream recipes she suggested contained butter, which was far from economical. In 1935, a pound of butter cost 17d, while the same amount of margarine was $101 / 2 \mathrm{~d} .{ }^{62}$ Despite this, consumption statistics indicate that most Australians preferred butter to margarine. ${ }^{63}$ The use of butter suggests that the shelf stability of mock

\footnotetext{
59 'The Household', Northern Star, 1 September 1877, 2. Emphasis in the original.

60 'Milk Problem - Housewives View', The Weekly, 24 June 1933, 24.

${ }^{61}$ Ruth Furst, 'Twenty of the Most Luscious Fillings', The Weekly, 10 August 1935, 31.

${ }^{62}$ This equates to $\$ 6.14$ per pound for butter and $\$ 3.81$ per pound for margarine in 2017 prices.

${ }^{63}$ In 1938-39, Australians consumed $14.9 \mathrm{~kg}$ of butter per capita per annum as compared to $1.8 \mathrm{~kg}$ of margarine.

Walker and Roberts, 91-92.
} 
cream, its ability to withstand the heat, and its potential to add 'extra goodness' to the housewife's baking, was a more important motivation for its use than its economy. ${ }^{64}$

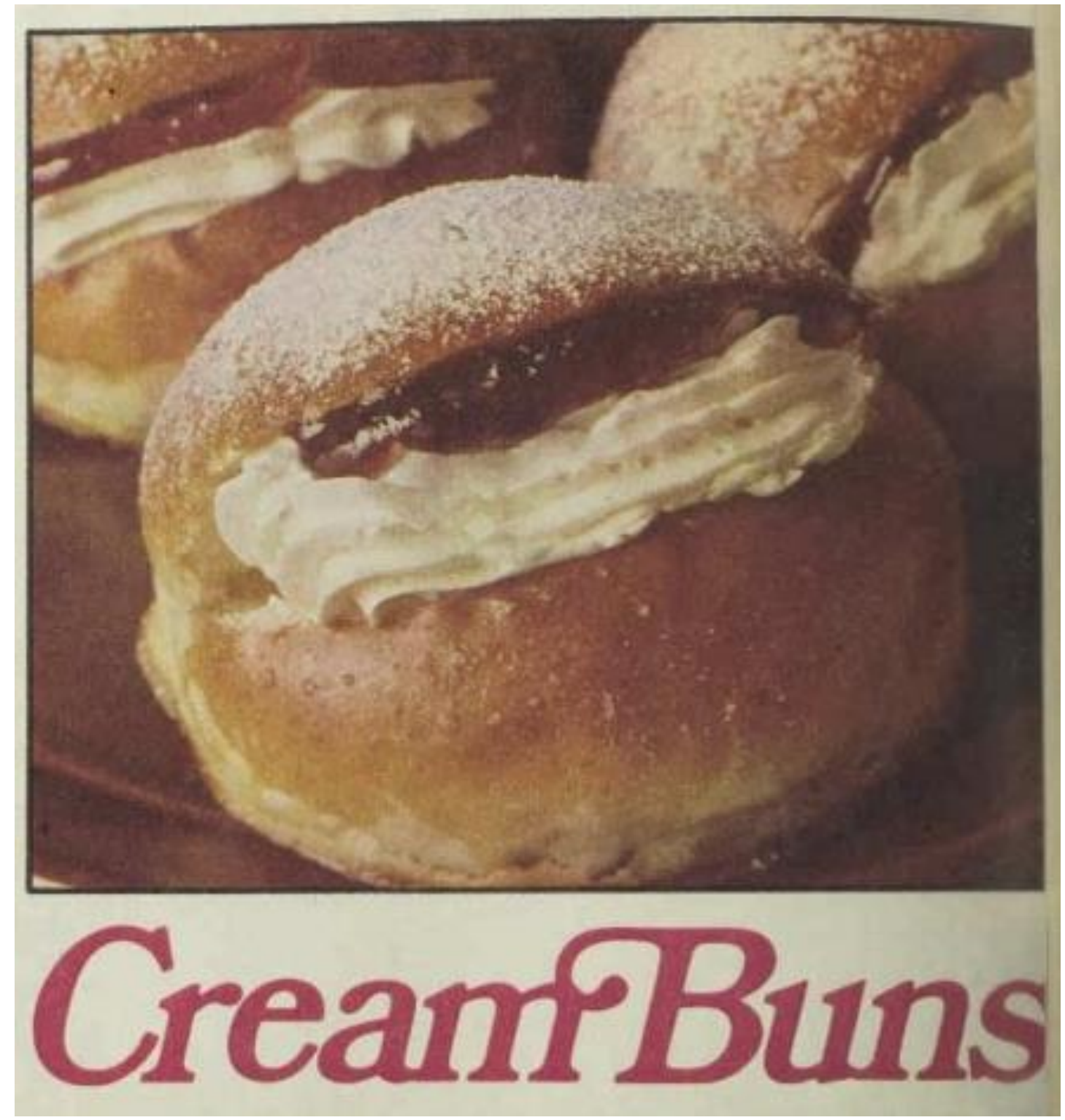

Figure 3 Mock cream was the star of recipes for cream buns. This recipe created mock cream from sugar syrup whipped with butter. 'Cream Buns', The Weekly, 14 April 1976, 76.

During the war years, the creation of mock cream became a decidedly frugal affair. Butter was removed entirely from many recipes. Miss R. J. Walker provided five recipes for mock cream in April 1942, stating that 'with cream off the menu in many areas, these

${ }^{64}$ Furst. 
substitutes will fill the bill'. ${ }^{65}$ She set out those five recipes not only in order of preference, but in order of frugality: the first recipe contained a quarter of a pound of butter, which would be an unthinkable luxury once butter rationing was introduced in July 1942. The 'quick' recipe that Miss Walker provided was a mixture of mashed banana, lemon juice, jam and icing sugar which bore little resemblance to actual cream. ${ }^{66}$ Of the 70 recipes for mock cream found in the magazine, 21 recipes for mock cream were published during the 1940s. 17 were published between 1940 and 1945. The many recipes for mock cream published during war time indicates of the centrality of cake and desserts to the Australian diet. In straitened circumstances, Australian families did not forego 'fripperies' such as cakes and desserts. They may have even become more important as symbols of normality, family and domesticity in the face of hardship.

Due to its role in baking, mock cream became an integral component of Australian food culture. While mock cream recipes disappeared from British newspapers after the end of wartime rationing, they continued to be published in Australia. ${ }^{67}$ In Britain, where most mock cream recipes were based on the traditional custard-like mixture of cornflour, milk and sugar, mock cream was disparaged as being inferior to fresh cream. ${ }^{68}$ Baking was very important to Australian women, and the domestic cook's reputation was reliant on her ability to successfully make cakes, biscuits, pies and puddings. ${ }^{69}$ Baked goods were the food of celebration, the food of display, and they were an opportunity for women to demonstrate their skill, to introduce variety into the family diet and show their imagination and ingenuity. ${ }^{70}$

\footnotetext{
65 'Every recipe wins a prize...', The Weekly, 4 April 1942, 35.

${ }^{66}$ Ibid. This recipe was published four times during the 1940s.

${ }^{67}$ Term frequency analysis for the phrase 'mock cream' in the British Newspaper Archive shows an increase from 76 articles containing the phrase 'mock cream' during the 1930s to 862 in the 1940s. During the 1960s, only 32 articles contained the phrase 'mock cream'.

${ }^{68}$ Marguerite Patten, We'll Eat Again: A Collection of Recipes from the War Years (London: Hamlyn, 1990), 61. Examination of British newspapers for the period 1930-80 reflect similar recipes; Gretel Beer, 'Why Mock Cream?', The Daily Telegraph (London), 12 June 1962, 9.

${ }^{69}$ Santich, 187.

${ }^{70}$ Kingston, 'From Patty Cake to Cup Cake', 86.
} 
Thus, the 1960s saw almost as many recipes for mock cream published in the magazine as the 1940s, although these were increasingly provided by the food editor, rather than by readers. ${ }^{71}$ The majority of mock creams in the 1960s were composed of equal parts butter and sugar 'washed' with water and flavoured with an essence like vanilla. These were not the thrifty mock creams of the 1940s. The mock cream recipes of the 1960s were also entirely confined to fillings and frostings for cakes, unlike during the 1930s and 1940s where mock creams were found in varying guises, like 'Mock Cream Mould'. ${ }^{72}$

Changing tastes in Australian baking contributed to the proliferation of mock cream recipes in the Weekly during the 1960s. By the 1960s, plain cakes such as the fruit cake and seed cake (which were generally un-filled and un-iced) had made way for highly decorated confections utilising various flavoured frostings and fillings, including mock cream. Whereas in the 1930s and 1940s, mock cream had been a response to scarcity, by the 1960s it was a necessary component of the popular iced layer cake. The 1963 recipe for 'Chocolate Dream Sponge' is an example of the changing state of the cake in Australia. The recipe for 'Chocolate Dream Sponge' was complicated, but resulted in a dual-layer chocolate cake, filled and topped with mock cream and decorated with 'wedges' of toffee arranged in a 'cartwheel effect' supported by cherries. ${ }^{73}$ The cake element of the cake was becoming 'insignificant', merely a 'vehicle for elaborate fillings and frostings', including mock cream. ${ }^{74}$ As Australia moved away from austerity, so too did its cakes.

These extravagant, layered cakes were a product of American influence. From the mid-nineteenth century, the 'prime virtues' of the American cake were its 'height and

\footnotetext{
${ }^{71}$ By the 1960s, food editorials were becoming more substantial with multiple pages in every edition dedicated to features from the Leila Howard Test Kitchen.

72 'Delicious Sweets', The Weekly, 10 July 1937, 49.

73 'Coffee and Cakes', The Weekly, 21 August 1963, 49.

${ }^{74}$ Kingston, 'From Patty Cake to Cup Cake', 76.
} 
lightness of texture', and frosting was the central element of cake decoration. ${ }^{75}$ In

constructing these cakes in Australia, however, mock cream as well as the imported 'frosting' were used. The 1960s saw the introduction of various American-inspired 'bake-off' contests in the magazine: an opportunity for women to win fabulous prizes such as a Ford Falcon, or a 'luxury 45-day cruise for two to Japan and the Orient' for their skill in baking. ${ }^{76}$ A number of the 'bake-off' winners used mock cream in their elaborate creations. Miss Helen Gray, for example, won 'National Princess 1963' in the Marville Margarine-sponsored National Baking Quest with her original recipe for 'Golden Fluff Cake'. The cake was a four-layered lemon flavoured sponge, with a lemon filling, slathered with mock cream. ${ }^{77}$

By the 1970s and 1980s, there was little need for mock cream. Refrigeration and low dairy prices meant that home cooks could use fresh cream in recipes that required it as an accompaniment or topping. During these decades, the Weekly nostalgically positioned mock cream as essential in baking 'Australian classics', like the cream bun or the neenish tart, further reinforcing its importance. In 1976, the food editor asked readers if they remembered cream buns, filled with mock cream, 'from schooldays'. A 1978 feature claimed that neenish tarts were 'old favourites - delicious little tarts with a fluffy mock cream filling' ${ }^{78}$ Mock cream was thus linked to Australian baking traditions. In wider society, as home baking fell out of fashion during the 1970s, Australians were more likely to purchase their baked goods

\footnotetext{
${ }^{75}$ Anne Byrn, American Cake (New York: Rodale, 2016); Nicola Humble, Cake: A Global History (London: Reaktion Books, 2010), 67; Analysis of newspapers from across the USA using Chronicling America shows that recipes for mock cream, particularly for use in baking were scarce; 'frosting' was integral to American baking culture.

${ }^{76}$ Several sponsored 'bake-offs' ran throughout the 1960s. The two major competitions, which both ran for several years, were sponsored by Marville Margarine and by the Australian Dairy Board in conjunction with White Wings (perhaps in response to Marville's competition!). Marville National Baking Quest, Advertisement, 12 June 1963, The Weekly; Margaret Berkeley, 'Baking Queen Wins Big Trip', The Weekly 23 September 1964, 13; 1967 Butter/White Wings Bake Off, Advertisement, 9 August 1967, The Weekly.

77 Given the sponsorship of the competition, Grey's mock cream was made with margarine, rather than butter. Kerry Yates, 'Baking Prize to Girl', The Weekly, 16 October 1963, Teenagers' Weekly Section, 3.

78 'Cream Buns', The Weekly, 14 April 1976, 76; 'Neenish Tarts', The Weekly, 4 January 1978, 81.
} 
from a supermarket. In this context, mock cream offered a longer shelf life and allowed commercially prepared cakes, slices, tarts and buns to remain unrefrigerated. While recipes for mock cream may have changed throughout the years in response to wider social forces, the concept of using an alternative for cream is still with us. Mock cream was adopted by Australians to deal with the environmental realities of living in a land where fresh cream was not a suitable ingredient and due to its popularity, usefulness, and role as a key ingredient of Australian baking, it became a part of our foodways.

\section{Conclusion}

The presence of mock foods in the Weekly provides a lens through which to view Australian domestic food culture. The rise and fall of mock food's popularity demonstrate the shift in the cultural importance of various foodstuffs and the way that economic depression and war impacted the Australian plate. It also shows how Australians (especially women) dealt with economic scarcity and the Australian climate by adapting and improvising in the kitchen. As postwar affluence arrived, and modern industrial food production impacted on affordability and availability, most mock foods disappeared from the Australian dinner table.

Nevertheless, there were still exceptional imitation foods that continued to play an integral role in Australian culinary culture during the second half of the twentieth century.

Mock chicken and mock cream are two examples that demonstrate the changing concept of 'good taste' in Australia. Mock chicken, made from 'inferior' protein sources such as rabbit and tripe, disappeared once real chicken became affordable. As chicken lost its association with higher-class cuisine, recipes designed to fake it disappeared. Mock cream, 
on the other hand, remains an important part of Australian food culture as its creation and use was not simply a response to the scarcity of ingredients. Its shelf-stable properties and ability to withstand the heat of the Australian climate ensured that it remained useful even once fresh cream became a viable ingredient. Its popularity and longevity are also linked with its integral role in baking; an important element of Australian food culture.

Most importantly, mock foods are evidence that, contrary to some positions, Australian women cared about the quality of the food they created and served to their families. Evidence from the Weekly suggests that women were invested in innovative and aspirational ways of preparing food - and mock foods were one way that they achieved this. Foods such as champagne, oysters and foie gras were considered desirable but were out of reach for most middle-class Australians. So, in preparing them, discerning housewives were doing more than responding to scarcity, they were performing class aspirations. These women sought to re-frame concepts of 'good taste' in the face of hardship with their creativity, experimentation and improvisation - key elements of modern Australian food culture - and their efforts and contributions thus need to be examined more seriously. The care and aspiration of Australian women even in time of scarcity suggests the importance of cooking to gender and history in Australia. It also suggests the need to look again at the role of food in Australian culture before the era of postwar migration.

\author{
Lauren Samuelsson \\ University of Wollongong \\ Email: slauren@uow.edu.au
}

https://orcid.org/0000-0002-6756-8448 